\title{
Sustainable breeding objectives and possible selection response: Finding the balance between economics and breeders' preferences
}

\author{
Birgit Fuerst-Waltl, ${ }^{* 1}$ Christian Fuerst, $\dagger$ Walter Obritzhauser, $\ddagger$ and Christa Egger-Danner† \\ *Department of Sustainable Agricultural Systems, Division of Livestock Sciences, University of Natural Resources and Life Sciences Vienna \\ (BOKU), Gregor Mendel-Str. 33, A-1180 Vienna, Austria \\ †ZuchtData EDV-Dienstleistungen GmbH, Dresdner Str. 89/19, A-1200 Vienna, Austria \\ $\ddagger$ Department for Farm Animals and Veterinary Public Health, Institute of Veterinary Public Health, University of Veterinary Medicine, Vienna, \\ Veterinärplatz 1, A-1210 Vienna, Austria
}

\section{ABSTRACT}

To optimize breeding objectives of Fleckvieh and Brown Swiss cattle, economic values were re-estimated using updated prices, costs, and population parameters. Subsequently, the expected selection responses for the total merit index (TMI) were calculated using previous and newly derived economic values. The responses were compared for alternative scenarios that consider breeders' preferences. A dairy herd with milk production, bull fattening, and rearing of replacement stock was modeled. The economic value of a trait was derived by calculating the difference in herd profit before and after genetic improvement. Economic values for each trait were derived while keeping all other traits constant. The traits considered were dairy, beef, and fitness traits, the latter including direct health traits. The calculation of the TMI and the expected selection responses was done using selection index methodology with estimated breeding values instead of phenotypic deviations. For the scenario representing the situation up to 2016, all traits included in the TMI were considered with their respective economic values before the update. Selection response was also calculated for newly derived economic values and some alternative scenarios, including the new trait vitality index (subindex comprising stillbirth and rearing losses). For Fleckvieh, the relative economic value for the trait groups milk, beef, and fitness were 38,16 , and $46 \%$, respectively, up to 2016 , and 39,13 , and $48 \%$, respectively, for the newly derived economic values. Approximately the same selection response may be expected for the milk trait group, whereas the new weightings resulted in a substantially decreased response in beef traits. Within the fitness block, all traits, with the exception of fertility, showed a positive selection response. For Brown Swiss, the relative economic

Received February 26, 2016.

Accepted August 9, 2016.

${ }^{1}$ Corresponding author: birgit.fuerst-waltl@boku.ac.at values for the main trait groups milk, beef, and fitness were 48,5 , and $47 \%$ before 2016 , respectively, whereas for the newly derived scenario they were 40, 14, and $39 \%$. For both Brown Swiss and Fleckvieh, the fertility complex was expected to further deteriorate, whereas all other expected selection responses for fitness traits were positive. Several additional and alternative scenarios were calculated as a basis for discussion with breeders. A decision was made to implement TMI with relative economic values for milk, beef, and fitness with 38, 18, and $44 \%$ for Fleckvieh and 50, 5, and $45 \%$ for Brown Swiss, respectively. In both breeds, no positive expected selection response was predicted for fertility, although this trait complex received a markedly higher weight than that derived economically. An even higher weight for fertility could not be agreed on due to the effect on selection response of other traits. Hence, breeders decided to direct more attention toward the preselection of bulls with regard to fertility.

Key words: breeding objective, economic value, selection response, total merit index

\section{INTRODUCTION}

In animal breeding, the genetic merit of future generations needs to be improved to ensure adequately efficient production under future economic, natural, and social circumstances (Groen et al., 1997). According to Fewson (1993), all economically important traits should be considered in the breeding objective; thus, production and functional traits, the latter increasing profit by reducing costs, need to be taken into consideration. Realizing the economic and socioeconomic benefits, more and more countries have started to include functional traits in their cattle breeds' breeding objectives (e.g., Miglior et al., 2005). In Holsteins, Reents and Rensing (2009) observed a noticeable increase of functional traits in various countries' breeding objectives between the years 2000 to 2009. However, the inclusion of health traits is primarily reliant on indirect health 
traits (correlated traits) due to a lack of recording and genetic evaluation of direct health traits (disease diagnoses, direct observations of impaired health).

According to selection index theory (Hazel and Lush, 1942), which is the basis for the optimal weighting when selecting for more than one trait, the total merit index (TMI) represents the mathematical definition of the breeding objective. When all traits are estimated multivariately, the TMI may be calculated as

$$
\mathrm{TMI}=\mathrm{b}_{1} \mathrm{X}_{1}+\mathrm{b}_{2} \mathrm{X}_{2}+\ldots+\mathrm{b}_{\mathrm{n}} \mathrm{X}_{\mathrm{n}},
$$

where $\mathrm{n}$ is the number of traits, $\mathrm{b}$ the index weights, and $\mathrm{X}$ the breeding values. If results of different genetic evaluations are combined, individual breeding values and their reliabilities as well as economic values and genetic correlations between all traits considered need to be known. Economic values, as defined by Hazel (1943), represent the value of one unit superiority of a trait when all other traits in the aggregate genotype remain constant. If relative levels of economic values are correct, optimum levels of genetic improvement are possible (Groen et al., 1997).

To optimize the long-term genetic gain of Austrian cattle breeds, the project OptiGene started in 2011. Among the aims of this project was the optimization of breeding objectives and breeding programs as well as the improvement of the TMI calculation (Egger-Danner et al., 2015). As such, economic values needed to be re-estimated for the breeds Fleckvieh and Brown Swiss based on updated prices, costs, and population parameters. A working group (breeding goals) within the joint genetic evaluation team Austria/Baden-Württemberg/ Bavaria (Germany) was established to provide support. Working group members and experts in related fields from Austria, Germany, and the Czech Republic met regularly between 2013 and 2015 .

In Austria, the first TMI in cattle was introduced in 1998 (Fürst et al., 2016). Economic values in the TMI were based on the results described by Miesenberger (1997). In 2002, economic values in the TMI were adapted without prior derivation when establishing the joint genetic evaluation Austria/Baden-Württemberg/ Bavaria. A re-estimation (Lind, 2007) following the approach of Miesenberger (1997) provided the basis for the TMI of both breeds up to the year 2016. As health data were not available before 2006 (Egger-Danner et al., 2012a), Lind (2007) did not consider health traits other than the SCC including costs for mastitis. Since 2010 (Fleckvieh, dual-purpose Simmental; Fuerst et al., 2011) and 2013 (Brown Swiss; Fuerst and Egger-Danner, 2014), breeding values for mastitis, early reproductive disorders (retained placenta, puerperal diseases, and metritis), ovarian cysts, and milk fever have been published in the context of the joint Austrian-German genetic evaluation. Along with the introduction of the genetic evaluation for health traits in Brown Swiss, all health traits, with the exception of milk fever, were also included in the TMI. Preceding model calculations revealed a slight negative trend for udder health and fertility when direct health traits were not considered (Egger-Danner et al., 2012b). Economic values for early reproductive disorders, ovarian cysts, and milk fever were already derived by Fuerst-Waltl et al. (2010) by adapting the computer program originally used by Lind (2007). Following earlier studies in Fleckvieh and Brown Swiss (Fuerst-Waltl and Fuerst, 2010, 2012), a new routine genetic evaluation for the trait rearing losses has recently been developed; however, so far, no economic values have been derived for this trait.

The aims of the current study were therefore to derive economic values for dairy, beef, and functional traits and the breeds Fleckvieh and Brown Swiss. Based on the computer program described by Fuerst-Waltl et al. (2010), mastitis and SCC should be split into 2 separate traits and economic values for ketosis and rearing losses should also be calculated. Another aim of our study was to compare the expected selection response for the TMI with previous and newly derived economic values, but also for alternative scenarios considering the needs of breeders. These were previously collated by means of a questionnaire (Steininger et al., 2012; Egger-Danner et al., 2015) and were discussed further in the working group and in regional meetings of farmers in 2015. The challenge for the definition of a new TMI was to find the balance between economics and breeders' preferences.

\section{MATERIALS AND METHODS}

\section{Model for Deriving Economic Values}

A computer program originally designed to optimize management-related decisions on cattle farms (Amer et al., 1996) and modified for the estimation of economic values in cattle by Miesenberger (1997), Lind (2007), and Fuerst-Waltl et al. (2010) was used. A dairy herd with milk production, bull fattening, and rearing of replacement stock was modeled over an infinite planning term. All relevant revenues and costs were calculated per day. Daily results were weighted by the proportion of the respective cow classes and were summarized over the calving interval or until culling. Cow classes arose from the percentage of culls for infertility, involuntary, and voluntary reasons in each lactation (Table 1). According to Smith et al. (1986), changes that correct 
Table 1. Age structure for Fleckvieh and Brown Swiss represented by proportions (\%) of cow classes by lactation and fate (INV $=$ involuntary culling; FER = culling for infertility; VOL = voluntary culling, SUR = survivors) in the reference scenario

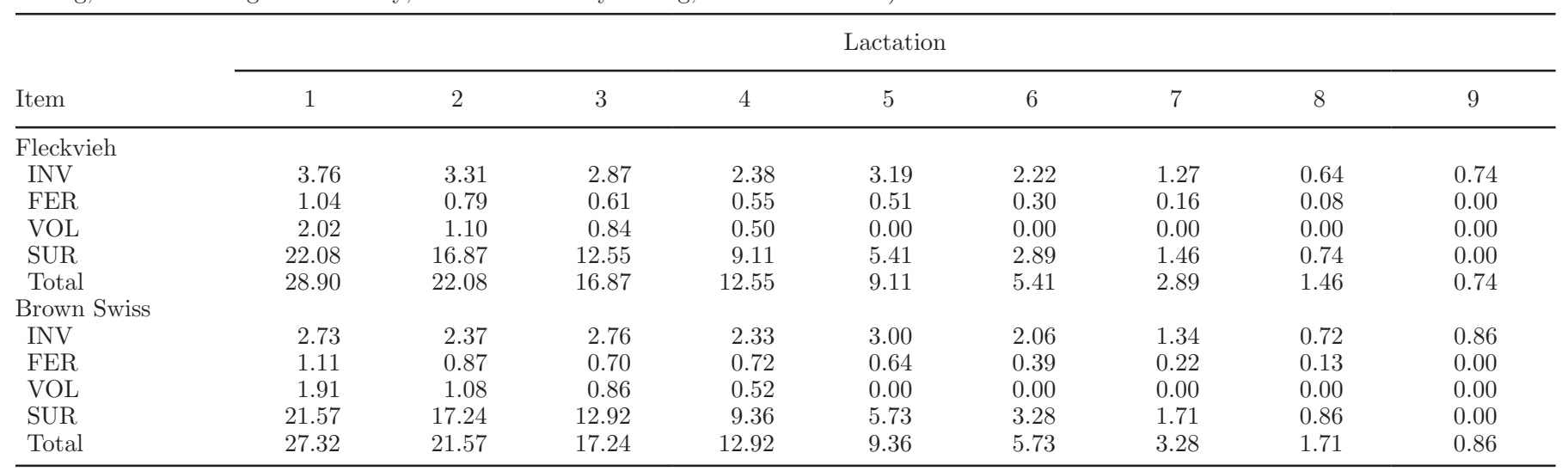

earlier inefficiency should not be counted as resources and are assumed to be efficiently used; hence, all costs (including fixed costs) were regarded as variable. The economic value of a trait was derived by calculating the difference in herd profit before (reference scenario) and after improvement by genetic change. Within the scenario, the herd distribution was maintained over time. In accordance with Dempfle (1992), double counting was avoided by deriving economic values separately for each trait while keeping all other traits constant. Results were expressed per average cow place and year. Reinsch (1993) proved that economic values per cow place and year are independent of discount rate and the initial state of the herd when assuming an infinite planning term. For each trait, the marginal utility in Euros per improvement of one unit and the economic value in Euros per genetic standard deviation was calculated. Furthermore, relative economic values for single traits and trait complexes were calculated; details are provided by Miesenberger (1997) and Lind (2007).

\section{Assumptions}

Table 1 shows the underlying age structure for Fleckvieh and Brown Swiss. Based on recent data evaluations of both breeds, the original underlying age structures (Lind, 2007) were adapted. Further population parameters were adopted from breed-specific annual reports (ZuchtData, 2014) and from genetic evaluations. Lactation yields in higher lactations were modeled by means of age factors. In both breeds, the highest milk yield was assumed in the fourth lactation (age factors 1.135 and 1.170 for Fleckvieh and Brown Swiss, respectively). The function described by Wood (1967) was used to estimate daily milk, fat, and protein yield during the first, second, and later lactations. Daily gains and live weights of fattening bulls were based on the function of Gompertz (Fitzhugh, 1976). An assortment of input parameters is presented in Table 2 .

Costs and prices (Tables 3 and 4 ) for labor, feedstuff, milk, carcasses, breeding animals, or inseminations are based on market reports, agricultural advisory data collections, and calculation tools in Austria, BadenWürttemberg, and Bavaria (e.g., www.ama.at; Over et al., 2013; Hamm et al., 2014). Average costs for disease treatments (Table 3 ) were provided by an Austrian veterinary group practice. Apart from costs for first and proportionate follow-up treatments and drugs, costs for farmers' additional labor time, laboratory analyses, as well as reduced returns due to an embargo on milk delivery after antibiotic use (statutory withdrawal period) were considered for mastitis, early reproductive disorders, and ketosis. As chronic and acute mastitis are treated as a combined trait in the genetic evaluation, their costs were weighted according to their occurrence (63 and 37\%, respectively). Possible culling due

Table 2. Population parameters for Fleckvieh and Brown Swiss (reference scenario)

\begin{tabular}{|c|c|c|}
\hline Input parameter & Fleckvieh & $\begin{array}{l}\text { Brown } \\
\text { Swiss }\end{array}$ \\
\hline Age at first calving (d) & 890 & 930 \\
\hline Live mass, cows (kg) & 750 & 750 \\
\hline Standard lactation (1st lactation, $\mathrm{kg}$ ) & 7,000 & 7,150 \\
\hline Fat content (1st lactation, \%) & 4.12 & 4.16 \\
\hline Protein content (1st lactation, \%) & 3.45 & 3.47 \\
\hline $\mathrm{SCS}^{1}$ & 3.3 & 3.6 \\
\hline Stillbirth rate $(\%)$ & 3.8 & 4.5 \\
\hline Length of productive life (yr) & 3.23 & 3.43 \\
\hline Age of heifers sold $(d)$ & 830 & 850 \\
\hline Live mass, fattening bulls (kg) & 720 & 690 \\
\hline Dressing percentage, bulls (\%) & 57.3 & 55.5 \\
\hline Proportion carcass grade $\mathrm{E}+\mathrm{U}^{2}(\%)$ & 64.5 & 17.1 \\
\hline Proportion difficult calving (\%) & 3.4 & 2.9 \\
\hline
\end{tabular}

${ }^{1} \mathrm{SCS}=\log 2(\mathrm{SCC} / 100,000)+3$.

${ }^{2} \mathrm{E}=$ excellent, $\mathrm{U}=$ very good carcass conformation. 
Table 3. Assumption costs and prices (in Euros)

\begin{tabular}{|c|c|}
\hline Trait & $€ /$ unit \\
\hline Labor costs (h) & 15 \\
\hline AI (case) & 30.50 \\
\hline Difficult calving/Cesarean (case) & $92.50 / 322.50$ \\
\hline Mastitis (diagnosis) & 340.55 \\
\hline Early reproductive disorders (diagnosis) & 283.00 \\
\hline Ovarian cysts (diagnosis) & 67.02 \\
\hline Milk fever (diagnosis) & 204.50 \\
\hline Ketosis (diagnosis) & 242.60 \\
\hline Slaughtered heifer FV/BS ${ }^{1}(\mathrm{~kg})$ & $3.50 / 3.10$ \\
\hline Replacement heifer FV/BS ${ }^{1}$ (animal) & $1,500 / 1,300$ \\
\hline Milk carrier/fat/protein (kg) & $0.11 / 3.06 / 3.82$ \\
\hline Slaughtered bull E/U/R/O/P² (class) & $3.70 / 3.65 / 3.61 / 3.19 / 2.70$ \\
\hline
\end{tabular}

to disease was not included in costs for health traits, as it is taken into account by the trait longevity. For SCS $\left[\mathrm{SCS}=\log _{2}(\mathrm{SCC} / 100,000)+3\right]$, reduced returns due to nonsaleable milk, increased labor time, proportionate laboratory ( $10 \%$ of animals with laboratory analyses and no mastitis diagnosis), and California Mastitis Test costs as well as quality-related reductions in milk price for SCS classes 5 (400,000-799,999 cells/mL) to 9 $(\geq 6,400,000$ cells $/ \mathrm{mL})$ were assumed.

Using the feedstuffs in Table 4, the linear planning algorithm of Press et al. (1986) was used to select a least-cost ration that meets the protein and energy requirements for each day. Differences in requirements because of live weight changes (growth and mobilization of body reserves) and gestation, as well as maximum feed intake capacity were taken into account (Miesenberger, 1997; Jeroch et al., 1999; Gruber et al., 2004). A maximum of $40 \%$ concentrate in the ration and a minimum of $18 \%$ fiber content were assumed.

\section{Considered Traits}

Economic values were derived for all traits currently included in the TMI, as well as for the potential new traits, milk fever, ketosis, and rearing losses. Dairy traits included milk carrier and fat and protein yield. For milk carrier, the daily milk yield was increased by the same amount throughout the lactation. Thus, the shape of the lactation curve remained constant, whereas fat and protein content were reduced to keep fat and protein yield constant. To derive economic values for fat and protein yield, contents were increased at constant milk yields.

Fattening traits included net daily gain, dressing percentage, and EUROP grading score (where $\mathrm{E}=$ excellent, $\mathrm{U}=$ very good, $\mathrm{R}=$ good, $\mathrm{O}=$ fair, and $\mathrm{P}=$ poor carcass confirmation). For net daily gain, the parameters of the Gompertz curve (Fitzhugh, 1976) were changed in alternative scenarios while keeping dressing percentage constant. Dressing percentage was increased incrementally by $1 \%$ while correcting for changes in net daily gain. As described by Miesenberger (1997), u-values of the standard normal distribution were assigned to class limits based on the proportions of animals in the different EUROP grading score classes. Subsequently, class limits were shifted toward the desired grades. New class limits resulted in new u-values and thus altered proportions of animals in different classes. For Fleckvieh, for example, the proportion of bulls in class $\mathrm{E}$ was $3.4 \%$ in the reference scenario, which corresponds to a $\mathrm{u}$-value of -1.82 . When the original $\mathrm{u}$-values of all classes were shifted by +0.25 , the proportion of bulls in class E increased to $5.8 \%$ (u-value -1.57). For both original and new ratios, weighted means for EUROP grading score (with $\mathrm{E}=5$ to $\mathrm{P}=1$ ) and price were determined, thereby enabling the calculation of approximated economic values.

In total, 13 functional traits were taken into account. Fertility traits are represented by conception rate, early reproductive disorders, and ovarian cysts. For these traits, improvements were made as one-percentage point incremental steps in conception rate or proportion of diseased animals. The same approach was applied for stillbirth rate, rearing losses (calf losses), mastitis, milk fever, and ketosis. Somatic cell count and calving ease are categorical traits, thus the same procedure as described above for the EUROP grading score was used. To derive economic values for length of productive life, the probability of involuntary culling was altered by one-percentage point steps in all lactations. Subsequent changes in herd structure resulted in a different level of profit. The trait milking speed is defined as kilograms

Table 4. Costs per kilogram of DM ( $€ / \mathrm{kg}$ of DM) and protein ( $\mathrm{g}$ of $\mathrm{CP})$, energy (MJ of ME), and fiber content for available feedstuffs

\begin{tabular}{lcccc}
\hline Feedstuff & $€ / \mathrm{kg}$ of DM & Protein $(\mathrm{g}$ of CP) & NEL $(\mathrm{MJ})$ & Fiber content \\
\hline Hay, 2nd cut & 0.20 & 133 & 5.28 & 0.284 \\
Grass silage & 0.18 & 150 & 6.10 & 0.213 \\
Corn silage & 0.16 & 131 & 6.48 & 0.210 \\
Barley & 0.17 & 124 & 8.28 & 0.057 \\
Soybean & 0.50 & 398 & 9.90 & 0.062 \\
\hline
\end{tabular}


of milk per minute to the power of 0.5. Economic values were derived by decreasing the time needed to milk 100 $\mathrm{kg}$ of milk. In the reference scenario, $4.67 \mathrm{~min} / 100 \mathrm{~kg}$ were assumed (Lind, 2007). Finally, the trait persistency was modeled by modifying the lactation curve resulting in different standard deviations of the daily milk yield. For this purpose, the b and c parameters of the Wood-curve were determined iteratively aiming at changes of one standard deviation while milk yield was kept constant. Genetic parameters had to be assumed as the breeding values for persistency are calculated from those for daily milk yield and thus no genetic parameters were available from routine genetic evaluation.

\section{TMI, Selection Response, and Decision- Making Process}

The calculation of the TMI and the expected selection response, assuming selection on TMI only, followed the selection index method as described by Miesenberger (1997) and Miesenberger et al. (1998). The TMI was calculated in accordance with the method described by Hazel and Lush (1942) using EBV instead of phenotypic deviations. Index weights (b) are calculated as

$$
\mathrm{b}=\mathbf{P}^{-1} \mathbf{G a}
$$

where $\mathbf{P}$ and $\mathbf{G}$ are the phenotypic and genetic (co) variance matrices and $\mathbf{a}$ is the vector of economic values. The covariances between breeding values $\left(\sigma_{\mathrm{xy}}\right.$ in the $\mathbf{P}$ matrix) are calculated as follows (Fuerst et al., 2014):

$$
\sigma_{x y}=r_{g x y} r_{x}^{2} r_{y}^{2} \sigma_{a x} \sigma_{a y}
$$

where $r_{g x y}=$ genetic correlation between traits $x$ and $y$, $r_{x, y}^{2}=$ reliabilities of EBV for traits $x$ and $y$, and $\sigma_{a x}, \sigma_{a y}$ $=$ additive genetic standard deviations of traits $x$ and $y$, respectively. Residual correlations are assumed to be zero (Fuerst et al., 2014) and individual index weights are computed by means of approximated reliabilities.

For the scenario representing the situation until April 2016 (scenario "old"), all traits included in the TMI were considered at their previous economic values. Single-trait breeding values (e.g., fat and protein yield, functional longevity, net daily gain) and subindex breeding values were used; subindex values include the fertility index and the udder health index. The fertility index comprises nonreturn rate and interval from first to last insemination for heifers and cows, and the direct health traits early reproductive disorders and ovarian cysts. In accordance with the derived economic values in 2010 (Fuerst-Waltl et al., 2010), the relative economic weights for nonreturn rate, interval from first to last insemination, early reproductive disorders, and ovarian cysts within the fertility index are $26.5,26.5,33$, and $14 \%$ for Fleckvieh and 25.5, 25.5, 34, and 15\% for Brown Swiss, respectively (Fuerst and Egger-Danner, 2014). For the fertility index, days open is considered as an auxiliary trait. The udder health index consists of the traits mastitis and SCS weighted 30 and $70 \%$, respectively. Furthermore, the udder conformation traits, fore udder attachment, udder depth and front (Fleckvieh) and rear (Brown Swiss) teat placement, are included as auxiliary traits (Fuerst and Egger-Danner, 2014). When direct health traits were included in the TMI in 2013 (Fuerst and Egger-Danner, 2014), weights within the udder health index were derived with regard to possible selection response (C. Fuerst, unpublished data). Recording of direct health traits is still not as comprehensive as that of SCC. Whereas data on SCC have been available for many years in Austria and Germany, monitoring of direct health data started as recently as 2006 in Austria, 2010 in Baden-Württemberg, and 2012 in Bavaria. The combination of partially missing data, lower heritability of mastitis, and thus lower reliabilities of breeding values, resulted in a decreased selection response in the udder health index once mastitis was included in the TMI. The final weighting of 30 and $70 \%$ for mastitis and SCC was therefore a compromise so that the direct health trait (mastitis) could be included in the index without dramatically reducing response to selection in this respect.

The vitality index, which was not included in the previous TMI, consists of stillbirth (born dead or died within 48 h; Fürst and Fürst-Waltl, 2006) and rearing losses. Rearing losses is composed of 3 traits: died between d 3 and 30 (both sexes), between d 31 and 10 mo (males), and d 31 and 15 mo (females). Economic values were derived for stillbirth and for a trait defined as rearing losses overall, rather than separately for the sexes and age ranges. Within the total rearing losses trait, the relative components were 50, 25, and $25 \%$ for Fleckvieh and 50, 0 and $50 \%$ for Brown Swiss, for the age ranges between $\mathrm{d} 3$ and 30 (both sexes), d 31 and 10 mo (males), and d 31 and 15 mo (females), respectively.

The expected selection response $(S R)$ was calculated as

$$
S R=\frac{\mathbf{G}^{\prime} b}{\sqrt{b^{\prime} \mathbf{P} b}}
$$

where $\mathbf{G}=$ genetic (co)variance-matrix, $b=$ weighting factors from the calculation of the TMI based on selection index theory (Hazel and Lush, 1942; Miesenberger, 
1997), and $\mathbf{P}=$ phenotypic (co)variance-matrix. The selection response is calculated assuming selection is based on individual cow performance. This is a rather simplistic approach compared with modeling a complex breeding program with different selection paths. However, previous studies (C. Fuerst and A. Willam, University of Natural Resources and Life Sciences, Vienna, Austria, unpublished data) showed that results gained in this way with respect to selection response are similar to those of more complex model calculations (e.g., by ZPLAN; Willam et al., 2008).

Several alternative scenarios were calculated as a basis for discussion with industry representatives. Apart from scenario "old" (TMI weights up to April 2016), the presentation shown to farmers included 12 (Fleckvieh) and 15 (Brown Swiss) different scenarios (data only partly shown). These alternative options were mostly based on a questionnaire (Egger-Danner et al., 2015; http://www.zar.at/Projekte/weitere-Projekte/OptiGene.html), where farmers were asked which traits they thought should be genetically improved over the next decade. In both breeds, fertility and longevity ranked first and second, with approximately $70 \%$ of farmers asking for a medium to very high level of improvement. Further traits highly ranked were persistency, udder, and udder health for Fleckvieh and milk content traits, udder, and udder health for Brown Swiss.

Aside from the scenario based on the newly derived economic values, both with and without taking milk carrier into account, alternatives with increased weights for fertility and longevity were calculated. Furthermore, an option with greater emphasis on protein yield, increased weights for udder health and persistency as well as the inclusion of milk protein percent (Brown Swiss), decreased weights for beef traits (Brown Swiss), and shifting of weights toward EUROP grading score within the beef subindex (Fleckvieh) were modeled. In some scenarios, the weight for milking speed and direct calving ease were set to zero. A strong positive genetic trend has been observed for milking speed in recent years due to the high correlation with milk yield. As milking speed is a trait with an intermediate optimum, the alternative scenarios with zero weighting should demonstrate the trend based on correlated response only. For direct calving ease, preselection usually occurs, especially when inseminating first-lactation cows. The mean breeding value for direct calving ease, for example, across all inseminations within the breed Fleckvieh was around 0.7 genetic standard deviations above average in 2015 (ZuchtData, 2015). For all alternative scenarios, the relative weights within udder health and fertility indexes were left unchanged. Adopting the derived weights for direct health traits would have resulted in lower selection responses, especially for udder health, and in decreased reliabilities of the breeding values (data not shown). As the direct health traits have only recently been included in the TMI (Fuerst and Egger-Danner, 2014), a consensus was reached that both within index weights were not to be altered when the new TMI was introduced in April 2016. As reliability for direct health traits will increase consistently, however, these within index weights will have to be adapted in the future.

All calculated scenarios (data only partly shown) were discussed by breeders and representatives of breeders' organizations in regional meetings in Austria, BadenWürttemberg, and Bavaria. After voting on economic values and desired selection responses of traits, suggestions for weights were proposed at each of these meetings. These suggestions were further discussed by a core group comprising approximately 20 members per breed (delegates of AI centers and breeding organizations, including breeders representing all countries) who agreed on the final decision. Presented in the current paper are the scenario "old," scenarios with weights according to the newly derived economic values, with 2 alternative weightings, and with the weights finally agreed upon. Furthermore, suggestions made in the regional meetings are shown in the Appendix. In alternative 1, milk carrier was included to account for the relatively high milk price as observed immediately before the end of the European Union milk quota. In alternative 2, the relative weight of the fertility index was increased, whereas weights for milking speed and calving ease direct were set to zero. Additionally, as Fleckvieh is a dual-purpose breed, a higher weight was put on beef, shifting weight from net daily gain to EUROP grading score within the trait complex. In addition, the udder health index was strengthened somewhat. In Brown Swiss, the weight on beef was reduced, a wider fat yield-to-protein yield ratio was assumed, and the weight for persistency was increased.

\section{RESULTS AND DISCUSSION}

\section{Economic Values}

In Tables 5 and 6 , the marginal utilities, genetic standard deviations $\left(\boldsymbol{\sigma}_{\mathrm{A}}\right)$, and economic values per genetic standard deviation are shown for Fleckvieh and Brown Swiss, respectively. Marginal utilities are related to an improvement in the trait mean by one unit and are expressed per average cow place and year. Economic values are calculated by multiplying the marginal utilities with the genetic standard deviations of the traits.

For Fleckvieh, similar economic values were found for milk carrier and fat and protein yield ( $€ 41.04$, €43.10, and $€ 45.10$ per $\sigma_{\mathrm{A}}$, respectively; Table 5), whereas for 
Table 5. Marginal utility (MU), genetic standard deviation $\left(\sigma_{\mathrm{A}}\right)$, economic value per $\sigma_{\mathrm{A}}\left(\mathrm{ev} / \sigma_{\mathrm{A}}\right)$ for all traits and relative economic values [ev (\%)] for traits considered for Fleckvieh before 2016

\begin{tabular}{|c|c|c|c|c|}
\hline Trait & $\mathrm{MU}(€ /$ unit $)$ & $\sigma_{\mathrm{A}}$ & $\mathrm{ev} / \sigma_{\mathrm{A}}$ & $\mathrm{ev}(\%)$ \\
\hline Milk carrier & 0.072 & 570 & 41.04 & \\
\hline Fat yield (kg) & 1.97 & 21.9 & 43.10 & 19.9 \\
\hline Protein yield (kg) & 2.75 & 16.4 & 45.10 & 20.8 \\
\hline Net daily gain $(\mathrm{g})$ & 0.662 & 30.5 & 20.19 & 9.3 \\
\hline Dressing percentage $(\%)$ & 5.63 & 1.1 & 6.19 & 2.9 \\
\hline EUROP grading score ${ }^{1}$ (class) & 13.0 & 0.25 & 3.25 & 1.5 \\
\hline Length of productive life (d) & 0.1304 & 180 & 23.47 & 10.9 \\
\hline Persistency ( $\sigma$ daily milk yield) & 9.23 & $1 \mathrm{~s}$ & 9.23 & 4.3 \\
\hline Conception rate $(\%)$ & 1.73 & 4.5 & 7.79 & 3.6 \\
\hline Calving ease (class) & 21.88 & 0.22 & 4.81 & 2.2 \\
\hline Stillbirth rate $(\%)$ & 2.8 & 4.0 & 11.20 & 5.2 \\
\hline Rearing losses (\%) & 3.58 & 2.87 & 10.27 & \\
\hline SCS (class) & 5.68 & 0.5 & 2.84 & 1.3 \\
\hline Mastitis (\%) & 3.65 & 4.34 & 15.84 & 7.3 \\
\hline Early reproductive disorders (\%) & 3.03 & 3.89 & 11.79 & 5.5 \\
\hline Ovarian cysts (\%) & 0.72 & 6.71 & 4.83 & 2.2 \\
\hline Milk fever $(\%)$ & 2.19 & 3.51 & 7.69 & \\
\hline Ketosis $(\%)$ & 2.60 & 0.70 & 1.82 & \\
\hline Milking speed $\left[(\mathrm{kg} / \mathrm{min})^{0.5}\right]$ & 79.53 & 0.084 & 6.68 & 3.1 \\
\hline
\end{tabular}

Brown Swiss a markedly higher economic value (€53.21 per $\sigma_{A}$; Table 6) was obtained for protein yield. In the TMI before 2016, the ratio of marginal utilities for fat and protein yield is 1:10 (data not shown) for both breeds. In agreement with Miesenberger (1997), much closer ratios of 1:1.4 (Fleckvieh) and 1:1.7 (Brown Swiss) were found in this investigation. The ratios are also comparable with the scenarios presented by Lind (2007) using the actual Bavarian milk price at that time (ratio of approximately 1:1.5 for both breeds). When the TMI was last revised in the year 2006, there was strong support from breeding organizations to increase the weight of protein yield, assuming a much higher future economic importance of protein. However, demand for European milk fat (butter) has not declined during the last decade. Milk fat is increasingly important for bakery and cream consumption. At the same time, an enhanced level of export has been recorded in the European Union (European Commission, 2015). Thus, the price for fat content of milk has not declined as expected. Furthermore, recent studies have suggested revising the widespread dietary guidelines, advising the consumption of fat-reduced milk and dairy products. High-fat dairy foods have not been found to contribute

Table 6. Marginal utility (MU), genetic standard deviation $\left(\mathrm{s}_{\mathrm{a}}\right)$, economic value per $\sigma_{\mathrm{A}}\left(\mathrm{ev} / \sigma_{\mathrm{A}}\right)$ for all traits and relative economic values [ev (\%)] for traits considered for Brown Swiss before 2016

\begin{tabular}{lcrrr}
\hline Trait & MU $(€ /$ unit $)$ & $\sigma_{\mathrm{A}}$ & $\mathrm{ev} / \sigma_{\mathrm{A}}$ & ev $(\%)$ \\
\hline Milk carrier (kg) & 0.067 & 543 & 36.38 & \\
Fat yield (kg) & 1.88 & 21.2 & 39.86 & 18.1 \\
Protein yield (kg) & 3.13 & 17.0 & 53.21 & 24.1 \\
Net daily gain (g) & 0.495 & 30.5 & 15.10 & 6.8 \\
Dressing percentage (\%) & 5.76 & 1.1 & 6.34 & 2.9 \\
EUROP grading score (class) & 45.51 & 0.25 & 11.38 & 5.2 \\
Length of productive life (d) & 0.1702 & 180 & 30.63 & 13.9 \\
Persistency ( $\sigma$ daily milk yield) & 2.67 & $1 \mathrm{~s}$ & 2.67 & 1.2 \\
Conception rate (\%) & 1.56 & 4.5 & 7.02 & 3.2 \\
Calving ease (class) & 19.49 & 0.22 & 4.29 & 1.9 \\
Stillbirth rate (\%) & 2.20 & 4.0 & 8.80 & 4.0 \\
Rearing losses (\%) & 2.96 & 3.45 & 10.21 & \\
SCS (class) & 6.41 & 0.5 & 3.21 & 1.5 \\
Mastitis (\%) & 3.63 & 4.34 & 18.48 & 8.4 \\
Early reproductive disorders (\%) & 3.02 & 3.89 & 11.05 & 5.0 \\
Ovarian cysts (\%) & 0.71 & 6.71 & 1.31 & 0.6 \\
Milk fever (\%) & 2.18 & 3.51 & 4.34 & \\
Ketosis (\%) & 2.59 & 0.70 & 1.81 & \\
Milking speed [(kg/min) $\left.)^{0.5}\right]$ & 79.53 & 0.084 & 6.96 & 3.2 \\
\hline
\end{tabular}

${ }^{1} \mathrm{E}=$ excellent, $\mathrm{U}=$ very good, $\mathrm{R}=$ good, $\mathrm{O}=$ fair, $\mathrm{P}=$ poor carcass conformation, with $\mathrm{E}=5$ to $\mathrm{P}=1$. 
as much to obesity or cardio-metabolic risk as previously thought (e.g., Kratz et al., 2013). The carrier charge associated with milk volume was not included in the previous TMI of both breeds. In earlier work (Miesenberger, 1997; Lind, 2007), no economic value or even a slightly negative value was assigned to milk carrier. The reason for the different result in our study is that the assumed milk price in the reference scenario was rather high, at $€ 0.375$ per $\mathrm{kg}$ of milk with $4.2 \%$ fat and $3.4 \%$ protein. In Austria, Baden-Württemberg, and Bavaria, a reduction in milk price is usually reflected in the price for the carrier rather than for content traits. When deriving economic values with a milk price of less than $€ 0.30$, which reflects the current situation following the termination of the European Union's milk quota system (data not shown), the marginal utility and, thus, the economic value of milk carrier is more or less zero. As pointed out by Lind (2007), functional and beef traits are hardly affected by changes in the pricing regimen of milk.

For beef traits, net daily gain revealed the highest economic value in both breeds (Tables 5 and 6). However, the ratio of net daily gain to dressing percentage to EUROP grading score differed markedly between the breeds; for Fleckvieh, the ratio was 68:21:11 whereas it was 46:19:35 for Brown Swiss cattle. The reason for the relatively low economic value for the trait EUROP grading score in Fleckvieh compared with Brown Swiss is the high proportion of bulls in the desired classes $\mathrm{E}$ and $\mathrm{U}$ and the small differences in the price for the classes $\mathrm{E}$ to R. Thus, an improvement of carcass quality has a much larger effect for Brown Swiss than for Fleckvieh. If the class distribution in Fleckvieh strongly deteriorates instead of improving (by about 2 genetic standard deviations), the derived economic value is more than doubled compared with an improvement (data not shown).

Length of productive life, representing the index trait functional longevity, has the highest economic value of functional traits in both breeds $\left(€ 23.47 / \sigma_{\mathrm{A}}\right.$ for Fleckvieh and $€ 30.63 / \sigma_{\mathrm{A}}$ for Brown Swiss). The main reason for the difference between breeds is the higher value of culled Fleckvieh animals. In Fleckvieh cows, the dualpurpose type is more pronounced than in Brown Swiss, resulting in higher prices for slaughter animals (€3.50 vs. €3.10 per kg; Table 3); hence, to a larger extent, Fleckvieh rearing costs are compensated by slaughter value. It should be noted that economic values for length of productive life are nonlinear (e.g Lind, 2007) and thus dependent on the mean population level. The assumptions in the reference scenario (Table 2) reflect a compromise between Austria and Germany. In Austria, the length of productive life is approximately 3.8 and $3.9 \mathrm{yr}$ for Fleckvieh and Brown Swiss (ZuchtData,
2014) whereas it is 2.8 and $3.3 \mathrm{yr}$ in Bavaria (LKV Bayern, 2014), respectively.

Mastitis has the second highest economic value of functional traits (Tables 5 and 6 ) in both breeds. Compared with mastitis, the relevance of SCC is markedly lower because as long as no veterinarian treatment is required and, more importantly, no embargo on milk delivery is required after antibiotic use; accordingly, the costs for increased SCC are rather low. Adding both traits together, udder health would account for economic values of $€ 18.64$ and $€ 21.69$ per genetic standard deviation in Fleckvieh and Brown Swiss, respectively. Thus, our economic values are similar to those determined by Lind (2007) and used in the "old" index.

Among fertility traits, the highest economic value was derived for early reproductive disorders (€11.79/ $\sigma_{\mathrm{A}}$ in Fleckvieh, $€ 11.05 / \sigma_{\mathrm{A}}$ in Brown Swiss; Tables 5 and 6), followed by conception rate and ovarian cysts. In total, the fertility index representing the fertility complex would have an economic value of $€ 24.41$ and $€ 19.38 / \sigma_{\mathrm{A}}$ for Fleckvieh and Brown Swiss, respectively. Compared with the first derivation of economic values for fertility-related direct health traits in Fleckvieh, a minor increase could be observed (Egger-Danner et al., 2012b).

Whereas the economic value for ketosis was slightly below $€ 2 / \sigma_{\mathrm{A}}$ in both breeds, differences between breeds were observed for milk fever $\left(€ 7.69 / \sigma_{\mathrm{A}}\right.$ in Fleckvieh, $€ 4.34 / \sigma_{\mathrm{A}}$ in Brown Swiss). Neither of these traits has been included in the TMI until now; a routine genetic evaluation only exists, at present, for milk fever. For all direct health traits, it should be noted that reduced profit due to culling was not taken into account to avoid double counting with regard to length of productive life.

For stillbirth rate and rearing losses, economic values around $€ 10 / \sigma_{\mathrm{A}}$ were estimated in both breeds, whereas the economic value for calving ease was $€ 4.81 / \sigma_{\mathrm{A}}$ for Fleckvieh and $€ 4.29 / \sigma_{\mathrm{A}}$ for Brown Swiss. Although the economic value for calving ease has increased since it was last derived in 2006 (Lind, 2007), it remains low; similar to direct health traits, only direct costs were taken into account. Neither the culling of cows nor dystocia-related health problems, such as retained placental membranes associated with a possible reduction of milk yield, were included in the calculation to prevent double counting.

The economic value for persistency is mainly the result of reduced costs for feed around lactation peak, as fewer concentrates are needed to meet nutrient requirements. Differences between breeds $\left(€ 9.23 / \sigma_{\mathrm{A}}\right.$ for Fleckvieh and $€ 2.67 / \sigma_{\mathrm{A}}$ for Brown Swiss) are caused by unequal lactation curves as starting points for the reference situation. 
Table 7. Genetic correlations between single traits and subindexes in the total merit index ${ }^{1}$

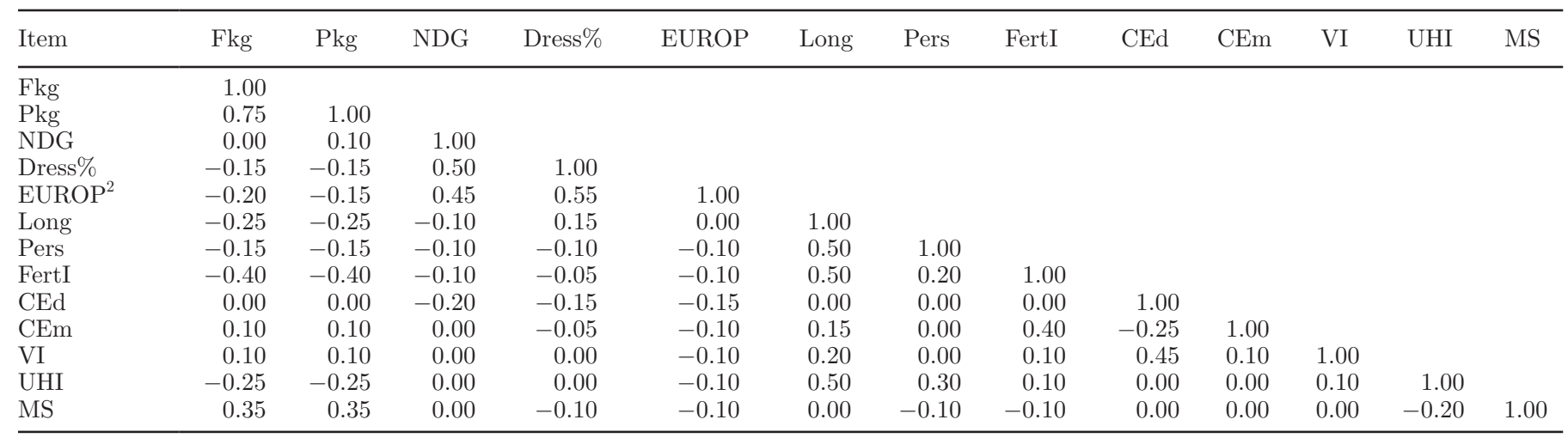

${ }^{1} \mathrm{Fkg}=$ fat yield, $\mathrm{Pkg}=$ protein yield, $\mathrm{NDG}=$ net daily gain, Dress $\%=$ dressing percentage, EUROP = EUROP grading score, Long $=$ functional longevity, Pers $=$ persistency, FertI $=$ fertility index, $\mathrm{CEd}$ and $\mathrm{CEm}=$ calving ease direct and maternal, $\mathrm{VI}=$ vitality index, UHI $=$ udder health index, $\mathrm{MS}=$ milking speed.

${ }^{2} \mathrm{E}=$ excellent, $\mathrm{U}=$ very good, $\mathrm{R}=$ good, $\mathrm{O}=$ fair, $\mathrm{P}=$ poor carcass conformation, with $\mathrm{E}=5$ to $\mathrm{P}=1$.

For milking speed, the economic value is similar for both breeds (€6.68/ $\sigma_{\mathrm{A}}$ for Fleckvieh and $€ 6.96 / \sigma_{\mathrm{A}}$ for Brown Swiss) and reflects lower costs due to a reduction in working time. However, the derived economic value is also dependent on the type of milking parlor; for example, in automatic milking systems, the economic value is virtually zero as long as the number of cows is not close to the maximum.

In both breeds, no economic values were derived for conformation traits, as they are not index traits but are considered auxiliary traits for longevity and udder health. Regardless of this, in an earlier study (FürstWaltl et al., 2004) potential economic values were derived for the 4 main conformation traits (frame, muscling, feet and legs/form, udder) based on auction sales data of herd book cattle. Results referred to an average reference animal; that is, an average heifer sold at auction. Depending on breed and the model applied, the benefit of a superior conformation (all traits summed up) was between $€ 70$ and $€ 200 / \sigma_{\mathrm{A}}$. To include conformation traits appropriately in the TMI, the economic values have to be related to an average herd book cow place and year. Hence, realization factors were determined based on the proportion of heifers sold at auction, which was approximately 3 to $5 \%$ at that time. The total economic value of conformation traits was, therefore, reported to be around $€ 10 / \sigma_{\mathrm{A}}$ (Fürst-Waltl et al., 2004). However, these realization factors are not quite correct, as only bidders who are not breeders from the same breeding program should be considered. Otherwise, the higher prices for the seller are equivalent to the higher costs for the purchaser. Thus, the actual realization factors will likely be substantially below the proportion stated above, resulting in economic values close to zero.

\section{Selection Response for Different TMI Scenarios}

Selection responses were calculated using scenario "old" and the newly derived economic values and for some additional scenarios. The genetic correlations in the index for both breeds are given in Table 7 . These correlations were estimated within the same project based on a multivariate 2-step approach as described by Pfeiffer (2015). Due to this methodology, genetic correlations could be estimated between traits for which only approximations were previously available. This had implications on the TMI, on the reliabilities, but also on the expected selection response (data not shown). In the following section, only results using the new correlation matrix are presented.

For Fleckvieh, the relative economic values for the trait groups milk, beef, and fitness were 38, 16, and $46 \%$ before 2016, respectively; for the newly derived economic values they were 39,13 , and $48 \%$, respectively (Table 8), excluding milk carrier and stillbirth maternal but including the vitality index. Whereas for the trait group milk more or less the same selection response may be expected, the new weightings resulted in a substantially decreased response in the beef traits; a markedly negative development is evident for the EUROP grading score. Within the fitness block, all traits but fertility show a positive selection response. The higher weight on fertility, by including early reproductive disorders and ovarian cysts, is not sufficient to reverse the negative trend. For Brown Swiss, the relative economic values for the main trait groups (milk, beef, and fitness) before 2016 were 48, 5, and 47\%, respectively, whereas for the newly derived scenario they were 40,14, and 39\%, respectively (Table 9). If the newly derived economic values were used to design 
Table 8. Comparison of expected selection response per generation in Fleckvieh when selecting for the previous total merit index (TMI; old), the TMI based on newly derived economic values (econ) or alternatives (alter1 and 2), and the agreed TMI 2016 (new; in \% of total response for trait groups milk, beef, and fitness, in kg for dairy traits and in EBV points, 12 points representing 1 genetic SD, for all other traits; higher values are desirable)

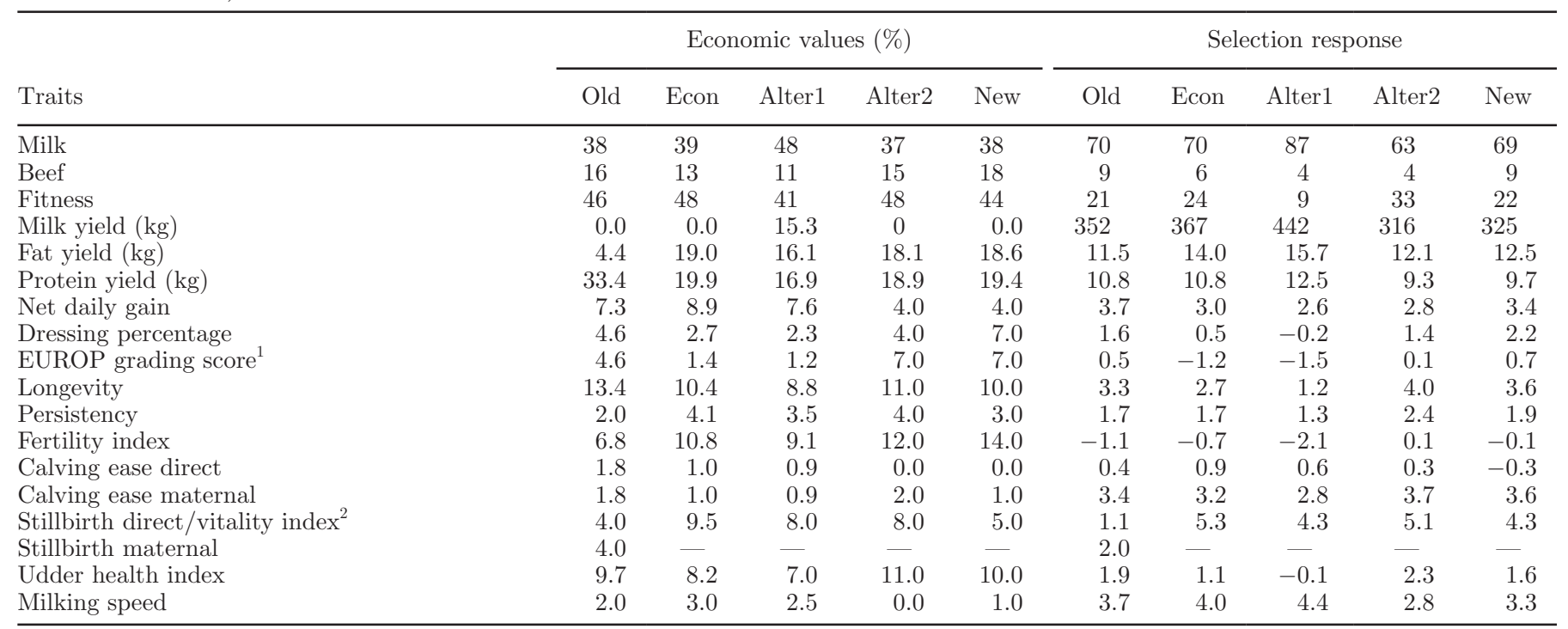

${ }^{1} \mathrm{E}=$ excellent, $\mathrm{U}=$ very good, $\mathrm{R}=$ good, $\mathrm{O}=$ fair, $\mathrm{P}=$ poor carcass conformation, with $\mathrm{E}=5$ to $\mathrm{P}=1$.

${ }^{2}$ The vitality index consisting of stillbirth and rearing losses replaces the trait stillbirth.

the TMI, the beef complex would have a nearly tripled weight compared with scenario "old." However, a negative response could still be observed for EUROP grading score. Similar to Fleckvieh, the fertility complex is also expected to further deteriorate, whereas all other expected selection responses for fitness traits are positive. For the new vitality index, a selection response of around 5 EBV points per generation (12 points representing 1 genetic standard deviation, positive values desirable) was estimated.

Table 9. Comparison of selection response per generation in Brown Swiss when selecting for the previous total merit index (TMI; old), the TMI based on newly derived economic values (econ) or alternatives (alter1 and 2), and the agreed TMI 2016 (new; in \% of total response for trait groups milk, beef, and fitness, in kg for dairy traits and in EBV points, 12 points representing 1 genetic SD, for all other traits; higher values are desirable)

\begin{tabular}{|c|c|c|c|c|c|c|c|c|c|c|}
\hline Traits & \multicolumn{5}{|c|}{ Economic values (\%) } & \multicolumn{5}{|c|}{ Selection response } \\
\hline Milk & 48 & 40 & 49 & 45 & 50 & 81 & 77 & 91 & 79 & 90 \\
\hline Fitness & 47 & 46 & 39 & 50 & 45 & 19 & 19 & 7 & 21 & 10 \\
\hline Milk yield (kg) & 0.0 & 0.0 & 13.6 & 0.0 & 0.0 & 343 & 363 & 430 & 348 & 371 \\
\hline Fat yield $(\mathrm{kg})$ & 4.8 & 17.3 & 14.9 & 16.5 & 20.7 & 12.1 & 13.7 & 15.1 & 13 & 14.6 \\
\hline Net daily gain & 2.2 & 6.6 & 5.7 & 3.0 & 3.0 & 1.1 & 2.7 & 2.4 & 0.9 & 0.9 \\
\hline Dressing percentage & 1.4 & 2.8 & 2.4 & 1.0 & 1.0 & -1.0 & 0.4 & -0.2 & -1.2 & -1.3 \\
\hline EUROP grading score ${ }^{1}$ & 1.4 & 4.9 & 4.3 & 1.0 & 1.0 & -2.0 & -0.7 & -1.1 & -2.5 & -2.6 \\
\hline Longevity & 16.1 & 13.3 & 11.5 & 14.0 & 12.0 & 3.0 & 2.4 & 1 & 3.3 & 2.2 \\
\hline Persistency & 2.7 & 1.2 & 1.0 & 3.0 & 3.0 & 2.2 & 1.1 & 0.7 & 2.2 & 1.7 \\
\hline Fertility index & 8.6 & 8.4 & 7.3 & 16.0 & 15.0 & -0.9 & -1.4 & -2.5 & 0.1 & -0.8 \\
\hline Calving ease direct & 0.9 & 0.9 & 0.8 & 0.0 & 0.0 & 0.5 & 0.6 & 0.5 & 0.2 & 0.2 \\
\hline
\end{tabular}

${ }^{1} \mathrm{E}=$ excellent, $\mathrm{U}=$ very good, $\mathrm{R}=$ good, $\mathrm{O}=$ fair, $\mathrm{P}=$ poor carcass conformation, with $\mathrm{E}=5$ to $\mathrm{P}=1$.

${ }^{2}$ The vitality index consisting of stillbirth and rearing losses replaces the trait stillbirth. 
Alternative 1, the inclusion of milk carrier, would lead to a strong selection response in the milk complex $(87$ and $91 \%$ of the total response for Fleckvieh and Brown Swiss, respectively), but also a deterioration in dressing percentage, EUROP grading score, fertility, and udder health. Apart from the fact that the economic value for carrier is more vulnerable to changes in milk price than that for milk content traits in the countries involved, the expected negative response in fertility and udder health does not correspond to breeders' preferences (Egger-Danner et al., 2015) or societal demands with respect to the use of antibiotics and animal welfare. As shown during the last decade, a strong positive genetic trend for milk yield is also expected without any weight in the TMI due to the high genetic correlation with fat and protein yield (Table 7). Besides, the breeding value for milk yield is generally used as a minimum performance criterion in breeders' decisions. In 2015, the average breeding value for milk yield across all inseminations was $675 \mathrm{~kg}$ for Fleckvieh and $510 \mathrm{~kg}$ for Brown Swiss (ZuchtData, 2015; estimated within breed).

In alternative 2, a positive selection response was observed for all traits for Fleckvieh. However, the response for fertility and EUROP grading score is still close to zero. Even though milking speed has no weighting in the TMI, a substantial positive response caused by the genetic correlation with milk traits may be observed. Whereas the fitness block is markedly strengthened, a lower selection response in the milk complex has to be accepted. With the exception of beef traits, similar results were found for Brown Swiss.

The various scenarios described were intensively discussed by breeders in regional meetings. The outcomes of these meetings, which were suggestions for weights in the new TMI after voting on economic values and desired selection responses, revealed regional differences (Table A1 and Table A2 in the Appendix). Fleckvieh breeders in Southern and Lower Bavaria markedly favored beef traits; a relative weight of $20 \%$ was suggested in both regions. Whereas, in Southern Bavaria, this additional weighting resulted in a lower weight of fitness traits, and the breeders in Lower Bavaria recommended a decrease in the weight of milk traits. Opposed to this, breeders in Baden-Württemberg were in favor of emphasizing the milk complex and milking speed with relative weights of 40 and $3 \%$, respectively. With 50,5 , and $45 \%$, the suggested relative weights for milk, beef, and fitness, respectively, were the same in the 3 regional meetings of Brown Swiss breeders. Only slight differences were observed; Austrian breeders proposed a protein content relative weight of $2.5 \%$.

Finally, a recommendation was made by the core group members, based on the new scenarios shown in Tables 8 and 9. The formal decision followed in Febru- ary 2016 and was officially introduced into the routine evaluation in April 2016. Simultaneously, the Czech Republic also adopted the TMI (Fleckvieh only). Farmers' preferences have also been considered in other countries when implementing new indexes for dairy cattle (e.g., Australia; Martin-Collado et al., 2015). By means of a survey and cluster analysis, 3 main types of farmers were identified in Australia, with a focus on production, functionality, or type. Based on the outcome of this study, 3 indexes were implemented: a primary and 2 alternative indexes, the latter with a stronger focus on functionality and type. The principle of designing alternatives is similar to our approach; generally based on derived economic values, weights of some traits were altered using a desired-gains approach. However, the intention of the decision process in our study was to find common ground for 1 TMI per breed. Several subindexes and all single breeding values are, however, available to all breeders, which enables them to choose bulls according to their individual breeding goals.

To strengthen the dual-purpose type, the relative economic values for milk, beef, and fitness selected for Fleckvieh were 38, 18, and 44\%, respectively. Although there was a relatively high weight on fertility, the selection response is still slightly below zero; for all other index traits, a positive development may be expected. For Brown Swiss, the relative weights for milk, beef, and fitness were 50,5 , and $45 \%$, respectively. As in the previous TMI, some weight was put on protein, and a slight negative trend was still observed. Similar to Fleckvieh, no positive expected selection response was predicted for fertility, although this trait complex received a markedly higher relative economic value than from economic principles (14.0 vs. $10.8 \%$ in Fleckvieh, 15.0 vs. $8.4 \%$ in Brown Swiss). An even higher weight on fertility could not be agreed on due to the lower expected selection response in other traits. Hence, Fleckvieh and Brown Swiss breeders decided to direct more focus on selecting bulls with higher breeding values for fertility rather than to further increase the index weight of this trait complex. In the era of genomics, a large number of young bulls is available, with both high breeding values for dairy traits and average or above average breeding values for fertility. For example, out of 73 Fleckvieh bulls with genomic information born in 2015 (breeding value database; ZAR, 2016), 54 have a minimum fertility index of $100(100=$ mean for all relative breeding values, 12 points represent 1 genetic standard deviation, values above 100 are desirable). Their average breeding value for milk yield is $873 \mathrm{~kg}$, and their TMI, milk, beef, and fitness index are 127, 121,106 , and 113, respectively. Bulls with fertility indexes below 100 points have average breeding values of $896 \mathrm{~kg}$ (milk yield), 123 (TMI), 123 (milk index), 
105 (beef index), and 103 (fitness index). Even though small differences in breeding values between the 2 groups of bulls were observed, a moderate preselection for bulls with at least average fertility indexes does not necessarily result in a noticeable reduced genetic gain in other traits.

\section{CONCLUSIONS}

The selection response calculations presented here reveal the expected genetic development when exclusively selecting according to TMI, which is not applicable in all practical cattle breeding situations. Certain minimum performance criteria (e.g., for milk yield, calving ease direct, and particularly for conformation) are usually applied. The actual selection response is largely dependent on the implementation of the breeding program at an industry level. The derivation of economic values showed that changes in revenue streams and costs, since the last update of the TMI, have not greatly changed the weights compared with the weights applied up to April 2016. Reaching a compromise between breeding objectives reflecting derived economic values and breeders' preferences is particularly challenging when a large number of traits are considered. Fertility is an example of the discrepancy between breeding objectives reflecting derived economic values and breeders' preferences. Breeders are aware that the fertility complex needs to be improved and realize that the weights needed result in unwanted lower gains in other traits. As additional actions need to be taken to strengthen fertility, breeding organizations have decided that a stronger focus will be put on the preselection of bulls. In addition to this, continued improvement of direct health traits' recording will also be beneficial. Nevertheless, the inclusion of direct health traits via the fertility and the udder health index, as well as the new trait vitality index, with appropriately high index weights are steps in the right direction toward responsible, forward-oriented, and socially accepted breeding goals. So far, the metabolic trait complex is disregarded in both breeds' TMI. However, positive genetic correlations within direct health traits, but also between direct health traits and functional longevity, may result in a correlated selection response. Even so, the establishment of an additional index comprising traits reflecting the metabolic trait complex and possibly claw health or feet and legs should be contemplated.

\section{ACKNOWLEDGMENTS}

We gratefully acknowledge the funding of the project OptiGene (Optimization of long-term genetic progress of Austrian cattle breeds with emphasis on health and genomic selection, project no. 100808) by the Austrian Federal Ministry of Agriculture, Forestry, Environment and Water Management (Vienna), the Federations of Austrian Fleckvieh (Zwettl, Austria), Brown Swiss (Innsbruck, Austria), Pinzgauer (Maishofen, Austria), Holstein (Traboch, Austria), and Tyrolean Grey Cattle (Innsbruck, Austria), and the Federation of Austrian Cattle Breeders (ZAR; Vienna). We particularly thank the members of the breeding goals working group within the joint genetic evaluation team Austria/BadenWürttemberg/Bavaria for many fruitful discussions and suggestions. The costs for diseases were determined in cooperation with the K-project ADDA, Advancement of Dairying in Austria. This project is supported by BMVIT (Austrian Ministry for Transport, Innovation and Technology, Vienna), BMWFW (Federal Ministry of Science, Research and Economy, Vienna, Austria), the province of Lower Austria and the city of Vienna in the framework of COMET-Competence Centers for Excellent Technologies. The COMET program is handled by the FFG (Austrian Research Promotion Agency, Vienna). We thank Clair Firth (University of Veterinary Medicine, Vienna, Austria) for English language assistance, and the anonymous reviewers, as well as the section editor Jennie Pryce for providing many valuable suggestions for improvements.

\section{REFERENCES}

Amer, P. R., A. Kaufmann, and N. Künzi. 1996. Breed choice and pricing system implications for farmers and political institutions from a Swiss cattle farm model. Pages 253-258 in Livestock Farming Systems. Research, Development, Socio-Economics and the Land Manager. J. B. Dent, M. J. McGregor, and A. R. Sibbald, ed. EAAP Publ. No. 79, Wageningen Academic Publishers, Wageningen, the Netherlands.

Dempfle, L. 1992. Berücksichtigung von Fruchtbarkeit und Eutergesundheit in der Rinderzüchtung. Zuchtungskunde 64:447-457.

Egger-Danner, C., B. Fuerst-Waltl, W. Obritzhauser, C. Fuerst, H. Schwarzenbacher, B. Grassauer, M. Mayerhofer, and A. Koeck. 2012a. Recording of direct health traits in Austria-Experience report with emphasis on aspects of availability for breeding purposes. J. Dairy Sci. 95:2765-2777.

Egger-Danner, C., C. Fürst, B. Fürst-Waltl, C. Pfeiffer, H. Schwarzenbacher, F. Steininger, and A. Willam. 2015. Optimierung der langfristigen züchterischen Entwicklung der österreichischen Rinderrassen unter besonderer Berücksichtigung der Gesundheit und der genomischen Selektion. Final report of the research project 100808. Accessed Jan. 10, 2016. https://www.dafne.at/ dafne_plus_homepage/download.php?t=ProjectReportAttachme $\mathrm{nt} \& \mathrm{k}=3703$.

Egger-Danner, C., A. Willam, C. Fuerst, H. Schwarzenbacher, and B. Fuerst-Waltl. 2012b. Effect of breeding strategies using genomic information on fitness and health. J. Dairy Sci. 95:4600-4609.

European Commission. 2015. Short Term Outlook for EU arable crops, dairy and meat markets in 2015 and 2016. Accessed Jan. 10, 2016. http://ec.europa.eu/agriculture/markets-and-prices/short-termoutlook/pdf/2015-03_en.pdf.

Fewson, D. 1993. Definition of the Breeding Objective. Design of Livestock Breeding Programmes. Animal Genetics and Breeding Unit, University of New England, Armidale, NSW, Australia. 
Fitzhugh, H. A. 1976. Analysis of growth curves and strategies for altering their shape. J. Anim. Sci. 42:1036-1051.

Fuerst, C., and C. Egger-Danner. 2014. Inclusion of direct health traits in the total merit index of Fleckvieh and Brown Swiss cattle in Austria and Germany. ICAR 39th Biennial Session, Berlin, Germany May 19-23. Accessed Jul. 28, 2016. http://www.icar. org/wp-content/uploads/2016/07/Inclusion-of-direct-healthtraits-in-the-total-merit-index-of-Fleckvieh-and.pdf.

Fuerst, C., A. Koeck, C. Egger-Danner, and B. Fuerst-Waltl. 2011. Routine genetic evaluation for direct health traits in Austria and Germany. Interbull Bull. 44:210-215.

Fuerst, C., C. Pfeiffer, H. Schwarzenbacher, F. Steininger, and B. Fuerst-Waltl. 2014. Comparison of different methods to calculate a total merit index - Results of a simulation study. Article no. 010 in Proceedings of the 10th World Congress on Genetics Applied to Livestock Production, Vancouver, Canada. Accessed Sep. 19, 2016. https://asas.org/docs/default-source/wcgalp-proceedingsoral/010_paper_9420_manuscript_632_0.pdf?sfvrsn=2.

Fuerst-Waltl, B., R. Baumung, C. Fuerst, A. Köck, W. Obritzhauser, H. Schwarzenbacher, J. Sölkner, A. Willam, P. Winter, and C. Egger-Danner. 2010. Gesundheitsmonitoring Rind: Entwicklung einer Zuchtwertschätzung für Gesundheitsmerkmale. Report of the research project 100250 BMLFUW-LE.1.3.2/0043-II/1/2007. Accessed Jan. 10, 2016. http://www.dafne.at/dafne_plus_ homepage $/$ index.php?section $=$ dafneplus \&content $=$ result $\& \&$ co me_from=homepage\&project_id=2704.

Fuerst-Waltl, B., and C. Fuerst. 2010. Mortality in Austrian dual purpose Fleckvieh calves and heifers. Livest. Sci. 132:80-86.

Fuerst-Waltl, B., and C. Fuerst. 2012. Effect of inbreeding depression on survival of Austrian Brown Swiss calves and heifers. J. Dairy Sci. 95:6086-6092.

Fürst, C., and B. Fürst-Waltl. 2006. Züchterische Aspekte zu Kalbeverlauf, Totgeburtenrate und Nutzungsdauer in der Milchviehzucht. Zuchtungskunde 78:365-383.

Fürst, C., C. Pfeiffer, and B. Fürst-Waltl. 2016. Fit, vital und leistungsstark - die neuen Zuchtziele für Fleckvieh und Braunvieh. Pages 41-48 in ZAR Seminar 2016, Neue Zuchtziele in der Rinderzucht, Fit, vital und leistungsstark in die Zukunft, Zentrale Arbeitsgemeinschaft österreichischer Rinderzüchter (ZAR), Vienna Austria. Accessed July 28, 2016. http://www.zar.at/Downloads/ ZAR-Seminar.html.

Fürst-Waltl, B., J. Wieser, C. Fürst, and J. Sölkner. 2004. Effect of conformation on the auction price of Simmental and Brown Swiss heifers. Zuchtungskunde 76:149-161. (Einfluss des Exterieurs auf den Versteigerungspreis von Fleckvieh- und Braunvieh-Kalbinnen).

Groen, A. F., T. Steine, J. J. Colleau, J. Pedersen, J. Pribyl, and N. Reinsch. 1997. Economic values in dairy cattle breeding, with special reference to functional traits. Report of an EAAP-working group. Livest. Prod. Sci. 49:1-21.

Gruber, L., F. J. Schwarz, D. Erdin, B. Fischer, H. Spiekers, H. Steingass, U. Meyer, A. Chassot, T. Jilg, A. Obermaier, and T. Guggenberger. 2004. Vorhersage der Futteraufnahme von Milchkühen - Datenbasis von 10 Forschungs- und Universitätsinstituten Deutschlands, Österreichs und der Schweiz. VDLUFA-Schriftenreihe 60:484-504. Accessed Jan. 10, 2016. http://www.vdlufa.de/ download/Kongressband_2004.pdf.

Hamm, L.-R., M. Heim, J. Weiß, and G. Dorfner. 2014. Landwirtschaftliche Erzeugerpreise in Bayern. LfL Grub, Bayern. Accessed January 10, 2016. http://www.lfl.bayern.de/mam/ cms07/iba/dateien/landwirtschaftliche_erzeugerpreise_in_ bayern_2004-2013.pdf.

Hazel, L. N. 1943. The genetic basis for constructing selection indexes. Genetics 28:476-490.

Hazel, L. N., and J. L. Lush. 1942. The efficiency of three methods of selection. J. Hered. 33:393-399.

Jeroch, H., W. Drochner, and O. Simon. 1999. Ernährung landwirtschaftlicher Nutztiere - Ernährungsphysiologie, Futtermittelkunde, Fütterung. Eugen Ulmer Verlag, Stuttgart, Germany.

Kratz, M., T. Baars, and S. Guyenet. 2013. The relationship between high-fat dairy consumption and obesity, cardiovascular, and metabolic disease. Eur. J. Nutr. 52:1-24.
Lind, B. 2007. Ableitung der Wirtschaftlichkeitskoeffizienten und optimalen Indexgewichte des Gesamtzuchtwertes für die deutschen Milch- und Zweinutzungsrassen unter Berücksichtigung aktueller und erwarteter zukünftiger Rahmenbedingungen. PhD Diss., Georg-August-Universität Göttingen, Germany.

LKV Bayern. 2014. Entwicklung des Abgangsalters und der Nutzungsdauer in bayerischen MLP-Betrieben. Accessed Jan. 10, 2016. http://www.lkv.bayern.de/lkv/medien/AbgangsalterMLP/ Abgangsalter\%20und\%20Nutzungsdauer\%202014_3.pdf.

Martin-Collado, D., T. J. Byrne, P. R. Amer, B. F. S. Santos, M. Axford, and J. E. Pryce. 2015. Analyzing the heterogeneity of farmers' preferences for improvements in dairy cow traits using farmer typologies. J. Dairy Sci. 98:4148-4161.

Miesenberger, J. 1997. Zuchtzieldefinition und Indexselektion für die österreichische Rinderzucht. PhD Diss., Universität für Bodenkultur Wien (BOKU), Austria.

Miesenberger, J., J. Sölkner, and A. Essl. 1998. Economic weights for fertility and reproduction traits relative to other traits and effects of including functional traits into a total merit index. Interbull Bull. 18:78-86.

Miglior, F., B. L. Muir, and B. J. Van Doormaal. 2005. Selection indices in Holstein cattle of various countries. J. Dairy Sci. 88:12551263.

Over, R., M. Köhler, K. Krieg, H. Nussbaum, and W. Wurth. 2013. Kalkulationsdaten Futterbau 3.8, 2014. Excel-Sheet compiled by LEL (Landesanstalt für Entwicklung der Landwirtschaft und der ländlichen Räume Schwäbisch Gmünd) and LAZBW (Landwirtschaftliches Zentrum für Rinderhaltung, Grünlandwirtschaft, Milchwirtschaft, Wild und Fischerei Baden-Württemberg Aulendorf. Version November 18, 2013.

Pfeiffer, C. 2015. Optimization of the total merit index of Austrian dairy cattle - Validation and adaptation of an approximate multitrait two-step procedure. PhD Thesis, University of Natural Resources and Live Sciences Vienna (BOKU), Austria.

Pfeiffer, C., C. Fuerst, V. Ducrocq, and B. Fuerst-Waltl. 2015. Genetic relationships between functional longevity and direct health traits in Austrian Fleckvieh cattle. J. Dairy Sci. 98:7380-7383.

Press, W. H., B. P. Flannery, S. A. Teukolsky, and W. T. Vetterling. 1986. Numerical Recipies: The Art of Scientific Computing. Cambridge University Press, Cambridge, UK.

Reents, R., and S. Rensing. 2009. Zuchtziele in der Milchrinderzucht national und international. Zuchtungskunde 81:397-405.

Reinsch, N. 1993. Berechnung wirtschaftlicher Gewichtungsfaktoren für sekundäre Leistungsmerkmale beim Fleckvieh. PhD Diss., Technische Universität, München, Germany.

Smith, C., J. W. James, and E. W. Brascamp. 1986. On the derivation of economic weights in livestock improvement. Anim. Prod. 43:545-551.

Steininger, F., B. Fuerst-Waltl, C. Pfeiffer, C. Fuerst, H. Schwarzenbacher, and C. Egger-Danner. 2012. Participatory development of breeding goals in Austrian dairy cattle. Acta Agric. Slov. 1:143147.

Willam, A., G. Nitter, K. Bartenschlager, K. Karras, E. Niebel, and H.-U. Graser. 2008. ZPLAN - Manual for a PC-Program to Optimize Livestock Selection Schemes. Manual Version 2008 for Source Code "z10.for". Institut für Nutztierwissenschaften, Department für Nachhaltige Agrarsysteme, Universität für Bodenkultur Wien, Vienna, Austria.

Wood, P. D. P. 1967. Algebraic model of the lactation curve in cattle. Nature 216:164-165.

ZAR. 2016. Zuchtwert-Datenbank. Accessed May 27, 2016. http://cgi. zar.at/cgi-bin/zw_default.pl.

ZuchtData. 2014. ZuchtData-Jahresbericht Ausgabe 2014. Accessed May 27, 2016. http://zar.at/Downloads/Jahresberichte/ ZuchtData-Jahresberichte.html.

ZuchtData. 2015. ZuchtData-Jahresbericht Ausgabe 2015. Accessed May 27, 2016. http://zar.at/Downloads/Jahresberichte/ ZuchtData-Jahresberichte.html. 


\section{APPENDIX}

Table A1. Comparison of expected selection response per generation for Fleckvieh when selecting for the total merit index (TMI) as suggested in regional meetings in Austria (AT), Baden-Württemberg (BW), and Bavaria (BY1 = Southern Bavaria, BY2 = Lower Bavaria, BY3 = Northern Bavaria; in \% of total response for trait groups milk, beef, and fitness, in kg for dairy traits and in EBV points, 12 points representing 1 genetic SD, for all other traits; higher values are desirable)

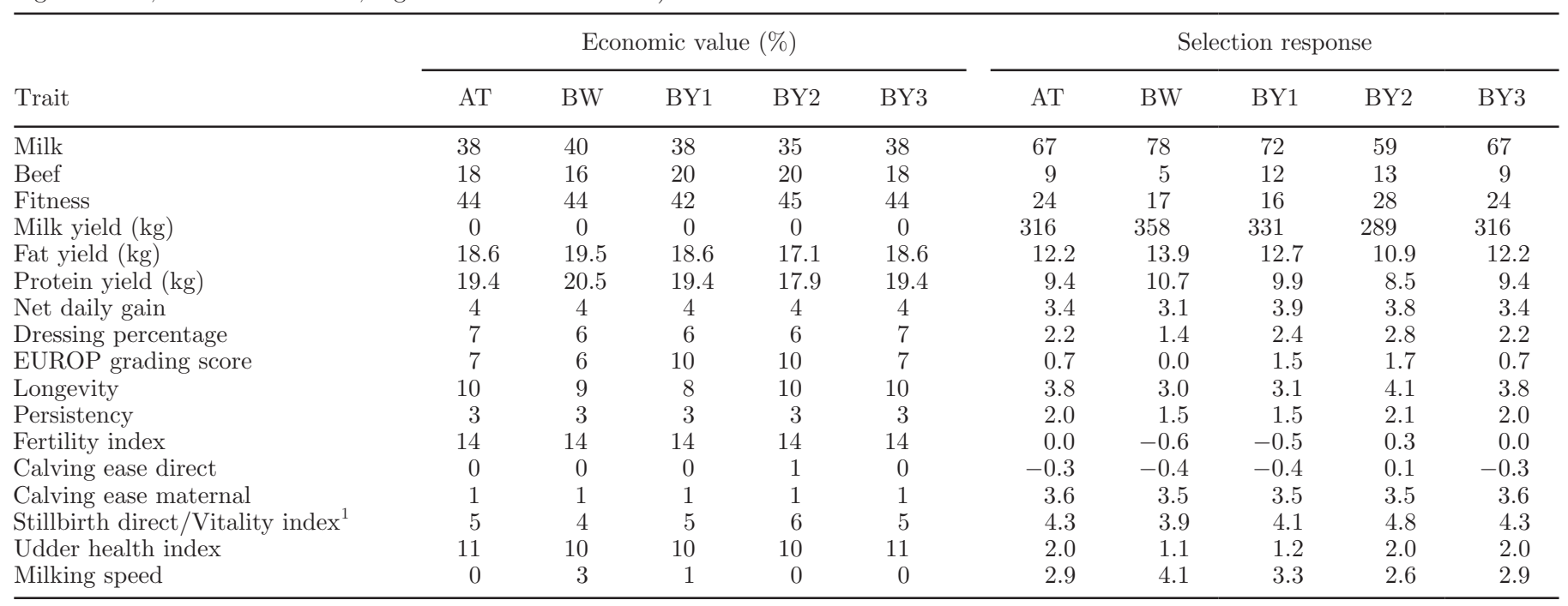

Table A2. Comparison of expected selection response per generation for Brown Swiss when selecting for the total merit index (TMI) as suggested in regional meetings in Austria (AT), Baden-Württemberg (BW), and Bavaria (BY; in \% of total response for trait groups milk, beef, and fitness, in $\mathrm{kg}$ for dairy traits and in EBV points, 12 points representing 1 genetic SD, for all other traits; higher values are desirable)

\begin{tabular}{|c|c|c|c|c|c|c|}
\hline \multirow[b]{2}{*}{ Trait } & \multicolumn{3}{|c|}{ Economic value (\%) } & \multicolumn{3}{|c|}{ Selection response } \\
\hline & $\mathrm{AT}$ & BW & $\mathrm{BY}$ & $\mathrm{AT}$ & BW & BY \\
\hline Milk & 50 & 50 & 50 & 89 & 94 & 92 \\
\hline Beef & 5 & 5 & 5 & 0 & -1 & 0 \\
\hline Fitness & 45 & 45 & 45 & 11 & 7 & 8 \\
\hline Milk vield $(\mathrm{kg})$ & 0 & 0 & 0 & 363 & 392 & 382 \\
\hline Fat yield (kg) & 20.5 & 18.4 & 21.5 & 14.4 & 14.9 & 14.8 \\
\hline Protein yield (kg) & 27.0 & 31.7 & 28.5 & 12 & 12.6 & 12.3 \\
\hline Protein percentage & 2.5 & 0 & 0 & -0.010 & -0.017 & -0.017 \\
\hline Net daily gain & 3 & 2 & 3 & 0.9 & 0.9 & 0.9 \\
\hline Dressing percentage & 1 & 1.5 & 1 & -1.3 & -1.4 & -1.3 \\
\hline EUROP grading score & 1 & 1.5 & 1 & -2.6 & -2.5 & -2.6 \\
\hline Longevity & 12 & 10 & 12 & 2.3 & 1.8 & 2.1 \\
\hline Persistency & 3 & 4 & 3 & 1.8 & 1.5 & 1.6 \\
\hline Fertility index & 15 & 15 & 15 & -0.7 & -1.2 & -0.9 \\
\hline Calving ease direct & 0 & 0 & 0 & 0.2 & 0.2 & 0.2 \\
\hline Calving ease maternal & 1 & 1 & 1 & 3.5 & 3.3 & 3.4 \\
\hline Vitality index & 4 & 4 & 4 & 3.6 & 3.4 & 3.5 \\
\hline Udder health index & 10 & 10 & 10 & 0.8 & 0.3 & 0.6 \\
\hline Milking speed & 0 & 1 & 0 & 3.8 & 4.1 & 3.9 \\
\hline
\end{tabular}

